\title{
Reduced dietary salt for prevention of cardiovascular disease (Unknown)
}

\author{
Hooper L, Bartlett C, Davey SG, Ebrahim S
}

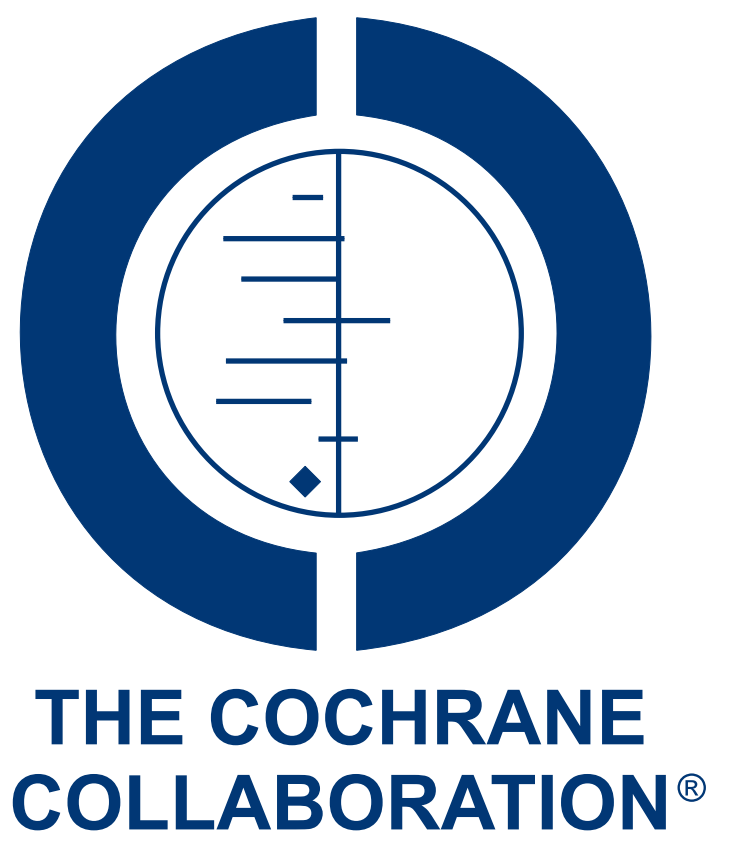

This is a reprint of a Cochrane unknown, prepared and maintained by The Cochrane Collaboration and published in The Cochrane Library 2003, Issue 2

http://www.thecochranelibrary.com

\section{WILEY}


TABLE OF CONTENTS

HEADER . . . . . . . . . . . . . . . . . . . . . . . . . . . . . . . . . . . . . . . . 1

ABSTRACT . . . . . . . . . . . . . . . . . . . . . . . . . . . . . . . . . . . . . . . . 1

PLAIN LANGUAGE SUMMARY . . . . . . . . . . . . . . . . . . . . . . . . . . . . . . . . . . . 2

BACKGROUND . . . . . . . . . . . . . . . . . . . . . . . . . . . . . . . . . . . . . .

OBJECTIVES . . . . . . . . . . . . . . . . . . . . . . . . . . . . . . . . . . . . .

RESULTS . . . . . . . . . . . . . . . . . . . . . . . . . . . . . . . . . . . . . . .

DISCUSSION . . . . . . . . . . . . . . . . . . . . . . . . . . . . . . . . . . . . . 5

ACKNOWLEDGEMENTS . . . . . . . . . . . . . . . . 7

SOURCES OF SUPPORT . . . . . . . . . . . . . . . . . . . . . . . . . . . . . . . . . . . 16 


\title{
[Intervention Unknown] \\ Reduced dietary salt for prevention of cardiovascular disease
}

\author{
L Hooper $^{1}$, C Bartlett, Smith G Davey, S Ebrahim \\ ${ }^{1}$ MANDEC, Manchester, UK \\ Contact address:
}

Editorial group: Cochrane Hypertension Group.

Publication status and date: Unchanged, published in Issue 4, 2003.

Citation: Hooper L, Bartlett C, Davey SG, Ebrahim S. Reduced dietary salt for prevention of cardiovascular disease. The Cochrane Database of Systematic Reviews (Complete Reviews), Issue . Art. No.: CD003656. DOI: 10.1002/14651858.CD003656.

Copyright (C) 2003 The Cochrane Collaboration. Published by John Wiley \& Sons, Ltd.

\begin{abstract}
A B S T R A C T
Background

Restricting sodium intake in elevated blood pressure over short periods of time reduces blood pressure. Long term effects (on mortality, morbidity or blood pressure) of advice to reduce salt in patients with elevated or normal blood pressure are unclear.
\end{abstract}

Objectives

To assess in adults the long term effects (mortality, cardiovascular events, blood pressure, quality of life, weight, urinary sodium excretion, other nutrients and use of anti-hypertensive medications) of advice to restrict dietary sodium using all relevant randomised controlled trials.

\section{Search strategy}

The Cochrane Library, MEDLINE, EMBASE, bibliographies of included studies and related systematic reviews were searched for unconfounded randomised trials in healthy adults aiming to reduce sodium intake over at least 6 months. Attempts were made to trace unpublished or missed studies and authors of all included trials were contacted. There were no language restrictions.

\section{Selection criteria}

Inclusion decisions were independently duplicated and based on the following criteria: 1) randomisation was adequate; 2) there was a usual or control diet group; 3) the intervention aimed to reduce sodium intake; 4) the intervention was not multifactorial; 5) the participants were not children, acutely ill, pregnant or institutionalised; 6) follow-up was at least 26 weeks; 7) data on any of the outcomes of interest were available.

\section{Data collection and analysis}

Decisions on validity and data extraction were made independently by two reviewers, disagreements were resolved by discussion or if necessary by a third reviewer. Random effects meta-analysis, sub-grouping, sensitivity analysis and meta-regression were performed.

\section{Main results}

Three trials in normotensives $(\mathrm{n}=2326)$, five in untreated hypertensives $(\mathrm{n}=387)$ and three in treated hypertensives ( $\mathrm{n}=801)$ were included, with follow up from six months to seven years. The large, high quality (and therefore most informative) studies used intensive behavioural interventions.

Deaths and cardiovascular events were inconsistently defined and reported; only 17 deaths equally distributed between intervention and control groups occurred. Systolic and diastolic blood pressures were reduced at 13 to 60 months in those given low sodium advice as compared with controls (systolic by $1.1 \mathrm{~mm} \mathrm{Hg}$, 95\% CI 1.8 to 0.4 , diastolic by $0.6 \mathrm{~mm} \mathrm{hg,} 95 \%$ CI 1.5 to -0.3 ), as was urinary 24

Reduced dietary salt for prevention of cardiovascular disease (Unknown)

Copyright $\odot 2003$ The Cochrane Collaboration. Published by John Wiley \& Sons, Ltd. 
hour sodium excretion (by $35.5 \mathrm{mmol} / 24$ hours, $95 \%$ CI 47.2 to 23.9). Degree of reduction in sodium intake and change in blood pressure were not related. People on anti-hypertensive medications were able to stop their medication more often on a reduced sodium diet as compared with controls, while maintaining similar blood pressure control.

\section{Reviewer's conclusions}

Intensive interventions, unsuited to primary care or population prevention programmes, provide only minimal reductions in blood pressure during long-term trials. Further evaluations to assess effects on morbidity and mortality outcomes are needed for populations as a whole and for patients with elevated blood pressure.

Evidence from a large and small trial showed that a low sodium diet helps in maintenance of lower blood pressure following withdrawal of antihypertensives. If this is confirmed, with no increase in cardiovascular events, then targeting of comprehensive dietary and behavioural programmes in patients with elevated blood pressure requiring drug treatment would be justified.

\section{PLAIN LANGUAGE SUMMARY}

\section{Synopsis}

This review set out to assess the long term effects of advice to cut down on salt in food on deaths, cardiovascular disease and blood pressure in adults.

Intensive support and encouragement to reduce salt intake did lead to reduction in salt eaten. It also lowered blood pressure but only by a small amount (about $1 \mathrm{mmHg}$ for systolic blood pressure, less for diastolic) after more than a year. This reduction was not enough to expect an important health benefit. It was also very hard to keep to a low salt diet. However, the reduction in blood pressure appeared larger for people with higher blood pressure.

There was not enough information to assess the effect of these changes in salt intake on health or deaths.

Evidence from a large and small trial showed that advice to reduce salt helps to maintain lower blood pressure following withdrawal of antihypertensive medication. If this is confirmed, with no increase in cardiovascular events, then comprehensive dietary and behavioural programmes in patients with elevated blood pressure requiring drug treatment would be justified.

See also the Cochrane review of short-term salt reduction trials: Jurgens 2003.

\section{B A C K G R O U N D}

There is evidence from published systematic reviews that restricting sodium intake in people with elevated blood pressure leads to reductions in blood pressure of about $4 \mathrm{~mm}$ hg systolic and 2 mm hg diastolic (Law 1991; Midgley 1996; Cutler 1997; Graudal 1998; Alam 1999; Jurgens 2003). However, within these reviews many included trials are short term, neither allowing for complete adjustment of blood pressure to altered sodium intake or to reduced motivation for following dietary restrictions over time. Also, some trials increased sodium intake in one arm and compared this with a reduced sodium intake in the other arm and so do not estimate likely effects of cutting down on sodium in a normal diet. In addition, some reviews suggest that the level of blood pressure reduction achieved over a longer period in free-living adults is less impressive than in the short term (Ebrahim 1996; Ebrahim 1998; Graudal 1998).

A decrease in blood pressure is only important if it results in a decrease in cardiovascular events and deaths. The published systematic reviews on the effect of salt restriction on blood pressure and other risk factor outcomes have expressed different interpretations with regard to the significance of these changes in relation to cardiovascular events and deaths. This systematic review and meta-analysis aimed to draw together information on the effect of long-term dietary salt reduction on health outcomes.

\section{O B J E C T I VES}

This systematic review aimed to study the effects of restricting 
sodium intake over at least six months in free-living adults, compared with a normal or usual sodium intake.

The specific objectives were to assess, in people with normal and elevated blood pressure, the effect of advice and/or support to reduce dietary sodium intake, on deaths and cardiovascular events; number and dose of anti-hypertensive medications used; quality of life; weight; systolic and diastolic blood pressure; and urinary sodium excretion and other nutrient intakes in free-living adults at least six months after the initial intervention was commenced.

The effects of potential modifiers of salt restriction (i.e. initial level of blood pressure, categorization into normal or elevated blood pressure, degree of sodium reduction, gender, race and age) were also investigated.

\section{RES U L T S}

Mortality and cardiovascular events.

These outcomes were inconsistently reported in trials (see Data - total deaths and cardiovascular events (including cardiovascular deaths)). No differences in periods of hospitalisation were seen between intervention groups in the HPT study (no further data were provided). Morgan 1978 reported that three control participants were treated for cardiac failure, as were two on low sodium diets, with four cardiovascular deaths in the low sodium group and two in the control group. TONE recorded cardiovascular events (including stroke, transient ischaemic attack, myocardial infarction, angina, congestive heart failure, arrhythmia and 'other' events) of participants. Cardiovascular events occurred in 46 control participants and 36 of those on low sodium diets. Pooling the two studies suggests no significant difference in cardiovascular morbidity between low sodium and control groups (relative risk 0.82, 95\% CI 0.56 to 1.21 ).

The trials report few deaths, altogether only 9 deaths in control groups and 8 in low sodium groups (relative risk $0.90,95 \% \mathrm{CI}$ 0.36 to 2.24 ). The available data are shown in the metaview.

Blood pressure.

Changes in blood pressure and urinary sodium excretion at intermediate and late assessments are given in Data - BP \& urinary sodium ('mean (sd)' for control / 'mean (sd)' for low salt) and meta-analysis results in Meta-analysis, sugrouping and sensitivity analysis results. Systolic blood pressure was reduced on a low salt diet at both intermediate (by $2.5 \mathrm{~mm} \mathrm{hg}, 95 \%$ CI 3.8 to 1.2 ) and late follow up (by $1.1 \mathrm{~mm} \mathrm{hg,} \mathrm{95 \%} \mathrm{CI} 1.8$ to 0.4 ). Diastolic blood pressure was also reduced at intermediate follow up (by $1.2 \mathrm{~mm}$ hg, $95 \%$ CI 1.8 to 0.7 ), less so later (by $0.6 \mathrm{~mm} \mathrm{hg}, 1.5$ to -0.3 ).

The few participants with very late follow up (seven years) had non-significant reductions in systolic (by $3.8 \mathrm{~mm} \mathrm{hg}, 95 \%$ CI 7.9 to -0.3 ) and diastolic (by $2.2 \mathrm{~mm} \mathrm{hg,} \mathrm{95 \%} \mathrm{CI} 4.8$ to -0.4 ) blood pressure. It should be noted that this late follow up of the TOHP phase I study was technically after the end of the trial. TOHP phase I ran for 18 months with a consistent intervention to help the low sodium group stick to a low sodium diet. The 7-year results are described as 'posttrial' results, and as 7 years follow up, and the trialists implied that they were assessing the long term effect of their 18 month intervention. We (as reviewers) felt that if the trial just stopped intervening, without altering the diets of either the intervention or control groups then we could include data from the later follow up (in many studies the intervention only happens once or twice at the beginning, but the effect is measured months later). The paper states that 'after 18-months, there was no further contact with the trial participants to enhance the intervention effect'. We could not contact the reviewers to confirm that there were no suggested alterations to the diets of the participants after the eighteen month intervention, so the data are included here but with this note of caution.

Statistical heterogeneity was present for systolic blood pressure at intermediate follow up and diastolic blood pressure at late follow up, but was resolved when sensitivity analyses removed trials with inadequate or unclear allocation concealment, or with imputed standard deviations, or when trials were sub-grouped into normotensive or hypertensive at baseline.

Sensitivity analysis, excluding trials with inadequate allocation concealment, resulted in all trials on untreated hypertensives being removed. As these trials were small, the effect on pooled estimates of blood pressure change was minor. Adding in data for the weight reduction arms of factorial trials strongly reduced the effect of low sodium advice on blood pressure, and slightly reduced the effect on sodium excretion (Meta-analysis, sugrouping and sensitivity analysis results).

Meta-regression of blood pressure change up to 12 months using all trials with relevant data (or trials with adequate allocation concealment, effectively trials on normotensives) showed no relationship with change in urinary sodium excretion, baseline systolic blood pressure or age (Meta-regression results, effects on SBP at 6 to 12 months). However, the meta-analyses subgrouping by 'normotensive' or 'hypertensive' participants at baseline did suggest a consistently greater effects of salt restriction on blood pressure in hypertensives. Insufficient data were available of effects on specific races or genders to enable statistical exploration of these factors.

Quality of Life.

Information on quality of life was patchy, with no common outcome measures. HPT asked participants whether they were having problems with their diets. $69 \%$ of those in the low sodium group reported problems at some time during the 3 years of the trial, and problems were reported at $42 \%$ of clinic visits. Problems related to the diet being inconvenient, conflicting with schedules, lack of time for planning, and difficulty in adherence while eating out.

TOHP phase I reported psychological well-being scores. These 
improved significantly in participants in the low sodium groups at 18 months compared with the non-intervention control group $(\mathrm{p}<0.01)$. It was stated that the improvement was generally consistent across race and sex subgroups but no further information was provided.

Thaler (Thaler men 1982; Thaler women 1982) reported that stopping adding salt at table was not difficult for participants, but many found cutting down on salt in cooking harder. The majority found their low salt bread (salt cut from $2.1 \%$ to $1.0 \%$ dry weight) and salt-free butter acceptable. Only $13 \%$ of participants reported their salt restricted diet as unpleasant or worse.

TONE found that the most common non-cardiovascular event recorded was headache: the low sodium group had a significant reduction in headaches as compared to the control group.

Thaler (Thaler men 1982; Thaler women 1982) asked about presence or absence of muscle cramps in control and low sodium participants. At eight months $13 \%$ of control subjects reported getting cramps a lot or sometimes (as opposed to occasionally or never) whilst this outcome was reported in $30 \%$ of the low sodium group.

Overall drop out rates were very similar (relative risk 1.04, 95\% CI 0.86 to 1.25 ) in low sodium compared with control groups.

Weight.

The suggestion from food diaries in HPT was that men on a low sodium diet take in roughly $240 \mathrm{kcal}$ less per day than their control counterparts. Women on low sodium diets take in 120 fewer kcal per day. This did not result in a large difference in weight; at 3 years those in the control group had gained about $1 \mathrm{~kg}$ on average more than those in the low sodium group.

TOHP phase I observed significantly greater weight loss in the low sodium group compared with control at six $(1.2 \mathrm{~kg})$ and twelve $(0.8 \mathrm{~kg})$ months, but the difference at 18 months $(0.4 \mathrm{~kg})$ was no longer significant. Similarly, in TOHP phase II those on a low sodium diet lost more weight initially $(1.2 \mathrm{~kg}$ difference at 6 months, $\mathrm{p}<0.001$ ), but the difference had disappeared by 36 months.

Arroll 1995 found a weight loss of $1.4 \mathrm{~kg}$ in the low sodium group relative to the controls at six months. However, Morgan 1987, Thaler (Thaler men 1982; Thaler women 1982), and Silman 1983 , found no change in weight in either control or low sodium groups.

In TONE eight participants not assigned to a weight loss intervention experienced excessive weight loss, but it is not clear how many of these were in the control or low sodium groups.

Overall, in the larger studies, where one is more likely to see any real effect, there appeared to be initial weight reductions accompanying the low sodium diet, but the effect was lost over several years.
Urinary sodium excretion.

Meta-analysis demonstrated a reduction in urinary 24 hour sodium excretion at intermediate $(48.9 \mathrm{mmol} / 24$ hours, $95 \% \mathrm{CI}$ 65.4 to 32.5$)$, and late follow up $(35.5 \mathrm{mmol} / 24$ hours, $95 \% \mathrm{CI}$ 47.2 to 23.9) in those advised to follow a low sodium diet compared with control. Significant heterogeneity was seen in results at intermediate and late assessment, and was not resolved by sensitivity analysis leaving out trials with unclear or inadequate allocation concealment. The one trial to assess very late outcomes (TOHP phase I, in normotensives) found that at seven years sodium excretion in a small subset of their original sample was similar in intervention and control groups.

Other nutrients.

The relationship between low sodium dietary advice and other dietary components has not been fully explored in these studies. Potassium is the most reported component, usually measured as urinary excretion alongside sodium. Other nutrients were measured as dietary intakes using food record and recall systems.

\section{Minerals}

Potassium. In HPT potassium excretion was consistently greater in low sodium than control groups (about $6 \mathrm{mmol} / 24$ hours at 3 years) but whether this difference was statistically significant is not clear. In TONE potassium intake was also greater in the low sodium group than in control (by $160 \mathrm{mg} / 24$ hours, $95 \% \mathrm{CI}$ 25 to 295). The rest of the trials found no significant differences in reported intakes or excretion of potassium including: TOHP phase I, TOHP phase II, Thaler men 1982, Thaler women 1982, Morgan 1978, Morgan 1987 and Silman 1983.

Magnesium. TONE found a higher intake of magnesium in low salt as compared with control groups (by $24 \mathrm{mg} / 24$ hour, $95 \% \mathrm{CI}$ 8 to 39), whereas TOHP phase I reported no significant difference between groups.

Calcium. TONE found a significant fall in calcium intake in the low salt as compared with the control group (of $71 \mathrm{mg} / 24$ hours, 95\% CI 119 to 23). HPT found a reduction in salt from dairy foods (suggested in all groups, but only significant in normal weight men), while TOHP phase I reported no significant net differences in reported intake of calcium.

Iron. TOHP phase I reported lower intakes of iron $(3.6 \mathrm{mg} /$ day at 18 months) in the low sodium group. The differences in iron were due to differences in men (women were similar between low sodium and control groups) and the reported iron intakes $(15 \mathrm{mg} /$ day at 18 months in men) in the low sodium group were still well over the RDA (10 mg/day for men). TONE also found lower iron intakes in the low sodium group (lower by $2.8 \mathrm{mg} / 24$ hours, $95 \%$ CI 3.8 to 1.8 ).

Phosphorus and zinc were not significantly different in low sodium and control groups in TONE. 
Vitamins.

TOHP phase I reported no significant net differences in reported intakes of vitamin $\mathrm{A}$, vitamin $\mathrm{C}$, thiamine, riboflavin or niacin. TONE found lower intakes of thiamine $(0.12 \mathrm{mg} / 24$ hours, $95 \%$ CI 0.22 to 0.02$)$ and riboflavin $(0.2 \mathrm{mg} / 24$ hours, $95 \%$ CI 0.3 to 0.1 ) in low sodium groups, but no significant differences in vitamins A, Bs, C, D, E, folate or niacin (excluding supplements).

Macronutrients.

Energy. TOHP phase I reported significantly lower daily intakes of total energy $(207 \mathrm{kcal})$ in the low sodium group, as did TONE (by $119 \mathrm{kcal} / 24$ hours, $95 \%$ CI 197 to 41 ).

Fats. Lower intakes of total fat (by $5.8 \mathrm{~g} / 24$ hours, $95 \%$ CI 10.1 to 1.5 ), saturated fat (by $2.4 \mathrm{~g} / 24$ hours, $95 \% \mathrm{CI} 4.0$ to 0.8 ) and monounsaturated fat (by $2.2 \mathrm{~g} / 24$ hours, $95 \%$ CI 4.0 to 0.4 ) were seen in the low sodium group of TONE. No significant differences were seen in polyunsaturated fat intake. TOHP phase I reported significantly lower daily intakes of total fat $(11.4 \mathrm{~g})$ in the low sodium group, but no significant net differences in saturated fat.

Alcohol. TOHP phase II reported that there were no differences between the low sodium and usual care groups in alcohol intake, while Arroll 1995 reported an increased intake of alcohol in the control group ( $2.4 \mathrm{~g} /$ day), though it was not clear whether this was statistically significant. TOHP phase I reported no significant net differences in reported intake of alcohol.

Protein and carbohydrates were not significantly different in the low sodium and control groups in TONE.

Overall, there is a trend towards increases in potassium and magnesium, and a fall in calcium, iron, some B vitamins, total energy, total and saturated fats in low sodium groups.

Anti-hypertensive medications used.

Two trials in patients with elevated blood pressure considered the ability of low salt diets to maintain blood pressure control after stopping anti-hypertensive medication. In the smaller trial (Morgan 1987) anti-hypertensive therapy was stopped two months after randomisation to usual or low sodium diet, but restarted if diastolic blood pressure rose. After six months, four of ten men on low sodium diet were taking anti-hypertensive medication, compared to nine of ten on usual diet (relative risk 0.44 , 95\% CI 0.20 to 0.98 ).

In the larger study (TONE, 975 participants, including those on weight reduction interventions) withdrawal of medication was attempted 3 months after randomisation to low sodium diet (with behavioural therapy) or usual care. The primary combined endpoint (a combination of high blood pressure at any visit, restarting of anti-hypertensive medication or any clinical cardiovascular event) was less common in the low sodium group, relative risk 0.83 (95\% CI 0.75 to 0.92 ), ARR 14\%, NNT 7.

\section{DISCUSSION}

Eleven long term randomised controlled trials of dietary salt reduction (including 3514 participants) provided few data on mortality (17 deaths in total), cardiovascular events or quality of life, but did demonstrate a significant decrease in systolic blood pressure (1.1 mm hg, 95\% CI 1.8 to 0.4$)$ and urinary sodium excretion ( $35.5 \mathrm{mmol} / 24$ hours, $95 \% \mathrm{CI} 47.2$ to 23.9 ) at 13 to 60 months after initial advice. The decrease in diastolic blood pressure was smaller $(0.6 \mathrm{~mm} \mathrm{hg}, 95 \% \mathrm{CI} 1.5$ to -0.3$)$. The data suggest that a low salt diet may help people on anti-hypertensives to stop their medication without losing blood pressure control. The data from TONE suggest that for every 7 patients assigned a goal of achieving a sodium intake of less than $80 \mathrm{mmol} /$ day, one would remain off antihypertensive medication with a BP less than 150/90 mm hg and with no adverse cardiovascular events.

Effects of low salt dietary advice on mortality and cardiovascular morbidity

Health promotion interventions involve several stages before any health outcome is seen. First, the advice must result in changed behaviour (cutting down on salt in foods) and secondly that behaviour must result in an improved health outcome (reduced cardiovascular illness, increased life expectancy). A major weakness of this review is that we were not able to assess the overall effect of advice to reduce dietary sodium on mortality or morbidity (as not enough events have been accumulated to see any definitive answer). Instead we have tried to follow the process by assessing several intermediate outcomes including urinary sodium excretion and blood pressure; however there may be effects on other risk factors.

It is not clear what effects a low sodium diet has on cardiovascular events and mortality. It has been suggested that lowering sodium intake may have adverse effects on the vascular endothelium through stimulation of the renin-angiotensin system (Alderman 1997), and adverse effects on serum total and LDL cholesterol levels (Graudal 1998) have been suggested. In cohort studies, lower salt intake in hypertensives has been associated with higher levels of cardiovascular disease (Alderman 1995) and in general populations (Alderman 1998; Tunstall-Pedoe 1997) with greater all-cause mortality. However, among obese people lower salt intake may be associated with reduced risk of cardiovascular events (He 1999; Tuomilehto 2001). These apparently contradictory findings emphasizes the fact that we do not know whether long-term salt restriction is beneficial or harmful.

Effects of low salt dietary advice on sodium excretion

The review suggests that sodium reduction of about a quarter of usual sodium intake in US and UK populations (MAFF 1999) can be achieved long term. This may be exaggerated. For example, HPT found that $48 \%$ of participants ate differently on the day of their food record, eating less food, and substituting simpler foods. 
Several people in the low sodium group also reported eating less salt on days salt intake was recorded. Whether food adjustment also occurred when urine samples were collected (and whether these were complete) is not known. Male participants in Thaler's trial (Thaler men 1982) were believed to have relaxed their salt restriction between urine samples (O. Simpson, personal communication, 2001)

Is it realistic to ask people to alter their salt intake long term? Advice to reduce dietary salt is common in primary care if the British Hypertension Society's Guidelines (Ramsay 1999; Ramsay 1999a) are being followed. These guidelines advise that 'reduced use of salt when preparing food and elimination of excessively salty foods from the diet' 'be offered to all hypertensive people and those with a strong family history of hypertension'. It does appear that the degree of salt restriction attained attenuates over time (Meta-analysis, sugrouping and sensitivity analysis results) and this occurs despite a great deal of ongoing encouragement and support (comprehensive interactive programmes of dietary and behavioural education involving specialized and highly trained staff, vast input of skills, time and materials) in all of the four large high quality trials. The resulting falls of $1.1 \mathrm{~mm}$ hg systolic and 0.6 $\mathrm{mm}$ hg in diastolic blood pressure may be useful at a population level; however the intensity of intervention applied to individuals required to achieve this is not realistic for community control of high blood pressure, which would need to be through changes in food production and catering practices.

Effects of low salt dietary advice on blood pressure

While both urinary sodium excretion and blood pressure fell, the salt reduction may not have caused the fall in blood pressure. Alterations in diet aimed at reducing salt intake may perhaps systematically affect other dietary components (such as alcohol, potassium, calcium, fat or energy intake) that may themselves alter blood pressure (Cappuccio 1991; Allender 1996; Whelton 1997; Ebrahim 1998; Brand 1999; Griffith 1999). The only available data suggest that potassium is not consistently affected by a low sodium diet, and that weight may be reduced in the medium term, but is unlikely to be exerting much effect on blood pressure by three years. Very little information is available on alcohol (suggesting no major effect), calcium (TOHP phase I reported no significant changes in intake of calcium, but HPT reported a reduction in salt from dairy foods) or fat (suggesting that significant reductions may be occurring in low sodium groups, reported in only one large trial). The significant reduction in weight of people given low sodium dietary advice in the medium, but not the longer term, may explain why the effect of a low sodium diet on blood pressure 'drops off' so much between intermediate and late follow up in this review. It may also explain why, in this review, no relationship is seen between the degree of reduction in sodium excretion and change in blood pressure. However the number of trials is small and relating a mean change in blood pressure to a mean change in urinary sodium is statistically weak. In previous meta-analyses
(Characteristics of systematic reviews on salt and blood pressure) a relationship has been seen in some cases but not in others. Individual participant data are required to take this issue further.

We expected that short duration trials would achieve larger falls in blood pressure that would attenuate over time, in line with attenuation of salt restriction. Trials in normotensives in in the Graudal review (Graudal 1998) (Characteristics of systematic reviews on salt and blood pressure) had a median length of 8 days, a reduction of $160 \mathrm{mmol} / 24$ hours in urinary sodium excretion and a fall of $1.2 \mathrm{~mm}$ hg in systolic blood pressure, while in this review (median trial length 36 months, $34 \mathrm{mmol} / 24$ hours difference in sodium excretion) systolic blood pressure fell by $1.1 \mathrm{~mm}$ hg. In hypertensives our results are less easy to interpret due to the low quality of included studies, but there is no clear suggestion that blood pressure effects diminish with longer duration trials or with smaller reductions in sodium excretion. This suggests that homeostatic mechanisms (Navar 1997) do not operate over the longer term to re-set usual blood pressure levels as might be expected. It has been suggested that 'usual' blood pressure may be set in utero or early childhood (Barker 1998) so it is possible that dietary salt intake in early childhood has a greater role in determining adult blood pressure than salt intake in adulthood; however the evidence is mixed (Lucas 1988; Hofman 1983; Singhal 2001), and open to varying interpretations (He 2001). A systematic review in this area would be helpful.

Part of the blood pressure lowering effect at longer follow up may be due to lower sodium diets preventing blood pressure rise with age. The Intersalt observational study (Elliott 1996) suggested that a population excreting $100 \mathrm{mmol} /$ day less sodium would experience a 10 and $6 \mathrm{~mm}$ hg lower rise in systolic and diastolic blood pressure over 30 years. This review suggests that voluntary reduction of only $35 \mathrm{mmol} \mathrm{Na} / 24$ hours is realistic for periods of over one year. This would prevent $3-4 \mathrm{~mm}$ hg systolic $(2 \mathrm{~mm}$ hg diastolic) blood pressure rise over thirty years. However, the sodium reduction achieved may decline over time so this additional protective effect of low salt advice may be limited.

The sodium reduction arms of the DASH (Sacks 2001) study are not included in this review as their intervention periods were only 30 days; however the strength of the study was in providing all food for participants and so tightly regulating sodium (as well as potassium and calorie) intake. Participants in the 'control intermediate sodium' arm reduced their sodium excretion by $35 \mathrm{mmol} /$ day compared with the 'control normal sodium' arm, reducing systolic (2.1 mm hg, 95\% CI 3.4 to $0.8 \mathrm{~mm} \mathrm{hg}$ ) and diastolic (1.1 $\mathrm{mm} \mathrm{hg,} \mathrm{95 \%} \mathrm{CI} 1.9$ to $0.2 \mathrm{~mm} \mathrm{hg}$ ) blood pressure by amounts similar to those seen in 13-60 month follow up in this review. With greater reductions in sodium, systolic blood pressure decreased by a greater amount ( $6.7 \mathrm{~mm} \mathrm{hg.} 95 \%$ CI 5.4 to 8.0 ).

Effects of low salt dietary advice on other outcomes

There is evidence that a low sodium diet improves the chance 
of maintaining controlled blood pressure following withdrawal of antihypertensives.

There are several reasons for assessing levels of other nutrients in a low sodium diet. Altering any one component of a complex diet will in turn alter the intake of many other micro and macronutrients. It is important to ensure that a low sodium diet is nutritionally adequate. It is also necessary to be aware that changes in many nutrients have their own long term effects on blood pressure and other aspects of cardiovascular health. The available data are scant but suggest increases in potassium and magnesium intake, and reductions in energy and total fat intakes, all of which might be expected to help reduce blood pressure in their own right as well as protecting against cardiovascular disease in other ways. This is good news for health, but raises further questions about the extent of the effect of salt reduction itself on blood pressure. It may be that the small changes in blood pressure seen in these long term trials are due to increases in potassium and decreases in fat intake. On the other hand, the reductions in calcium and iron seen in some trials might endanger dietary adequacy for a few people, increasing the risk of osteoporosis and anaemia. It may be that the effect on blood pressure, and more generally on health, of a low sodium diet depends on the types of messages used, the specific dietary measures taken. These may differ considerably from trial to trial, or even from participant to participant.

We have included only a small number of the many randomised controlled trials on the effect of salt manipulation, and none of the intra- or inter-population surveys, cohorts or animal trials that are commonly referred to when the effect of salt reduction on health is discussed. Most of the randomised controlled trials that have been performed have been of short duration and do not assess whether dietary advice has any long term effect on health outcomes or blood pressure. Despite an extensive search, only eleven trials fulfilled our inclusion criteria (determined by our question). Where randomised controlled trials in humans are available to answer a question on health, it would be inappropriate to include animal studies, surveys or cohort studies, which have contradictory results and interpretations (Taubes 1998).

\section{ACKNOW LEDGEMENTS}

Thanks to: all the trialists and experts who kindly provided unpublished information, including Professor Bruce Arroll (University of Auckland), Professor Olaf Simpson (Dunedin), Dr. Susan Tonascia (Johns Hopkins University), Professor Trefor Morgan (University of Melbourne), Professor Silman (University of Manchester); Dr John Hooper (for Danish translation); Lee's Ph.D. supervisors, Professor Paul Durrington and Dr Helen Worthington (both University of Manchester); Theresa Moore, Katherine Wornell and Margaret Burke of the Cochrane Heart Group; and Ciprian Jauca and Professor Jim Wright of the Cochrane Hypertension Group.

\section{R E F E R E N C E S}

\section{References to studies included in this review}

Alli 1992 \{published data only\}

* Alli C, Avanzini F, Bettelli G, Bonati M, Colombo F, Corso R, Di Tullio M, Gentile MG, Sangalli L, Taioli E, Tognoni G. Feasibility of a long-term low-sodium diet in mild hypertension. Journal of Human Hypertension 1992;6 (4):281-286. [MedLine: 93059176].

Arroll 1995 \{published and unpublished data\}

* Arroll B, Beaglehole R. Salt restriction and physical activity in treated hypertensives. N Z Med J 1995;108 (1003):266-268. [MedLine: 95365076].

Costa 1981 \{published data only\}

* Costa FV, Ambrosioni E, Montebugnoli L, Paccaloni L, Vasconi L, Magnani B. Effects of low-salt diet and of acute salt loading on blood pressure and intralymphatic sodium concentration in young subjects with borderline hypertension. Clinical Science 1981;61(Supplement 7): 21s-23s. [MedLine: 82094132].

HPT \{published and unpublished data\}

Borhani NO, Tonascia J, Schlundt DG, Prineas RJ, Jefferys

JL. Recruitment in the Hypertension Prevention trial.

Hypertension Prevention Trial Research Group. Controlled
Clin Trials 1989;10(3 Suppl):30S-39S. [MedLine: 90031597].

Brown KM, Oberman A, Van Natta ML, Forster JL.

Baseline characteristics in the hypertension prevention trial. Controlled Clinical Trials 1989;10(3 supplement):40S-64S. [MedLine: 90031598].

Forster JL, Jeffery RW, VanNatta M, Pirie P. Hypertension prevention trial: do 24-h food records capture usual eating behavior in a dietary study?. Am J Clin Nutr 1990;51(2): 253-257. [MedLine: 90164468].

* Hypertension Prevention Trial Research Group. The Hypertension Prevention Trial: three-year effects of dietary changes on blood pressure. Arch Intern Med 1990;150(1): 153-162. [MedLine: 90120838].

Jeffery RW, French SA, Schmid TL. Attributions for dietary failures: problems reported by participants in the Hypertension Prevention Trial. Health Psychol 1990;9(3): 315-329. [MedLine: 90255462].

Jeffery RW, Tonascia S, Bjornson BW, Schlundt DG, Sugars C for the Hypertension Prevention Trial Research Group. Treatment in the Hypertension Prevention Trial. Controlled Clin Trials 1989;10(3 Suppl):65S-83S. 
[MedLine: 90031599].

Meinert CL, Borhani NO, Langford HG. Design, methods, and rationale in the Hypertension Prevention Trial. Hypertension Prevention Trial Research Group. Controlled Clin Trials 1989;10(3 Suppl):1S-29S. [MedLine: 90031596].

Prud'homme GJ, Canner PL, Cutler JA. Quality assurance and monitoring in the Hypertension Prevention Trial. Hypertension Prevention Trial Research Group. Controlled Clin Trials 1989;10(3 Suppl):84S-94S. [MedLine: 90031600].

Schmid TL, Jeffery RW, Onstad L, Corrigan SA. Demographic, knowledge, physiological, and behavioral variables as predictors of compliance with dietary treatment goals in hypertension. Addictive Behaviors 1991;16(3-4): 151-160. [MedLine: 91289809].

Shah M, Jeffery RW, Laing B, Savre SG, Van NM, Strickland D. Hypertension Prevention Trial (HPT): food pattern changes resulting from intervention on sodium, potassium, and energy intake. Hypertension Prevention Trial Research Group. J Am Diet Assoc 1990;90(1):69-76. [MedLine: 90110778].

Morgan 1978 \{published and unpublished data\}

* Morgan T, Adam W, Gillies A, Wilson M, Morgan G, Carney S. Hypertension treated by salt restriction. Lancet 1978;1(8058):227-230. [MedLine: 78091122].

Morgan TO, Adams WR, Hodgson M, Gibberd RW. Failure of therapy to improve prognosis in elderly males with hypertension. Medical Journal of Australia 1980;2(1): 27-31. [MedLine: 81051857].

Morgan 1987 \{published data only\}

* Morgan T, Anderson A. Sodium restriction can delay the return of hypertension in patients previously well-controlled on drug therapy. Can J Physiol Pharmacol 1987;65(8): 1752-1755. [MedLine: 88079620].

Silman 1983 \{published data only\}

Silman AJ, Locke C, Humpherson P. Salt restriction and no drug treatment in mild to moderate hypertension [letter]. Lancet 1982;1(8277):903-904. [MedLine: 82172148].

* Silman AJ, Locke C, Mitchell P, Humpherson P. Evaluation of the effectiveness of a low sodium diet in the treatment of mild to moderate hypertension. Lancet 1983;1 (8335):1179-1182. [MedLine: 83217784].

Thaler men 1982 \{published and unpublished data\} * Thaler BI, Paulin JM, Phelan EL, Simpson FO. A pilot study to test the feasibility of salt restriction in a community. $N Z$ Med J 1982;95(721):839-842. [MedLine: 83142430].

Thaler women 1982 \{published and unpublished data\} * Thaler BI, Paulin JM, Phelan EL, Simpson FO. A pilot study to test the feasibility of salt restriction in a community. NZ Med J 1982;95(721):839-842. [MedLine: 83142430].

TOHP phase I \{published data only\}

Cook NR, Kumanyika SK, Cutler JA. Effect of change in sodium excretion on change in blood pressure corrected for measurement error. Am J Epidemiol 1998;148(5):431-444. [MedLine: 98407573].

He J, Whelton PK, Appel LJ, Charleston J, Klag MJ. Long-term effects of weight loss and dietary sodium reduction on incidence of hypertension. Hypertension 2000; 35(2):544-550. [MedLine: 20145848].

Kumanyika SK, Hebert PR, Cutler JA, Lasser VI, Sugars CP, Steffen BL, Brewer AA, Cameron M, Shepek LD, Cook $\mathrm{NR}$, et a. Feasibility and efficacy of sodium reduction in the Trials of Hypertension Prevention, phase I. Trials of Hypertension Prevention Collaborative Research Group. Hypertension 1993;22(4):502-512. [MedLine: 94011135]. Sacks FM, Hebert P, Appel LJ, Borhani NO, Applegate WB, Cohen JD, Cutler JA, Kirchner KA, Kuller LH, Roth KJ, et a. The effect of fish oil on blood pressure and high-density lipoprotein-cholesterol levels in phase I of the Trials of Hypertension Prevention. Trials of Hypertension Prevention Collaborative Research Group. J Hypertens Suppl 1994;12(7):S23-S31. [MedLine: 95287279].

Satterfield S, Cutler JA, Langford HG, Applegate WB, Borhani NO, Brittain E, Cohen JD, Kuller LH, Lasser NL, Oberman A, Rosner B, Taylor JO, Vogt TM, Walker G, Whelton PK for the Trials of Hypertension Prevention Collaborative Research Group. Trials of hypertension prevention. Phase I design. Ann Epidemiol 1991;1(5): 455-471. [MedLine: 94093770].

Stevens VJ, Corrigan SA, Obarzanek E, Bernauer E, Cook NR, Hebert P, Mattfeldt BM, Oberman A, Sugars C, Dalcin AT, Whelton PK for the TOHP Collaborative Research Group. Weight loss intervention in phase 1 of the Trials of Hypertension Prevention. Arch Intern Med 1993;153(7): 849-858. [MedLine: 93221340].

* The Trials of Hypertension Prevention Collaborative Research Group. The effects of nonpharmacologic interventions on blood pressure of persons with high normal levels: results of the Trials of Hypertension Prevention, Phase I. JAMA 1992;267(9):1213-1220. [MedLine: 92167528]

Whelton PK, Buring J, Borhani NO, Cohen JD, Cook N, Cutler JA, Kiley JE, Kuller LH, Satterfield S, Sacks FM, Taylor JO for the Trials Of Hypertension Prevention (TOPH) Collaborative Research Group. The effect of potassium supplementation in persons with a high-normal blood pressure. Results from phase I of the Trials of Hypertension Prevention (TOHP). Trials of Hypertension Prevention (TOPH) Collaborative Research Group. Ann Epidemiol 1995;5(2):85-95. [MedLine: 95316194]. Whelton PK, Hebert PR, Cutler J, Applegate WB, Eberlein KA, Klag MJ, Keough ME, Hamill S, Borhani NO, Hollis J, Oberman A for the Trials of Hypertension Prevention Collaborative Research Group et a. Baseline characteristics of participants in phase I of the Trials of Hypertension Prevention. Ann Epidemiol 1992;2(3):295-310. [MedLine: 94101134]

Whelton PK, Kumanyika SK, Cook NR, Cutler JA, Borhani NO, Hennekens CH, Kuller LH, Langford H, Jones DW, Satterfield S, Lasser NL, Cohen JD. 
Efficacy of nonpharmacologic interventions in adults with high-normal blood pressure: results from phase 1 of the Trials of Hypertension Prevention. Trials of Hypertension Prevention Collaborative Research Group. Am J Clin Nutr 1997;65(2 Suppl):652S-660S. [MedLine: 97174901]. Yamamoto ME, Applegate WB, Klag MJ, Borhani NO, Cohen JD, Kirchner KA, Lakatos E, Sacks FM, Taylor JO, Hennekens $\mathrm{CH}$. Lack of blood pressure effect with calcium and magnesium supplementation in adults with high-normal blood pressure. Results from Phase I of the Trials of Hypertension Prevention (TOHP). Trials of Hypertension Prevention (TOHP) Collaborative Research Group. Ann Epidemiol 1995;5(2):96-107. [MedLine: 95316195].

TOHP phase II \{published data only\}

Appel LJ, Hebert PR, Cohen JD, Obarzanek E, Yamamoto M, Buring J, Stevens V, Kirchner K, Borhani NO. Baseline characteristics of participants in phase II of the Trials of Hypertension Prevention (TOHP II). Trials of Hypertension Prevention (TOHP) Collaborative Research Group. Ann Epidemiol 1995;5(2):149-155. [MedLine: 95316191].

Hebert PR, Bolt RJ, Borhani NO, Cook NR, Cohen JD, Cutler JA, Hollis JF, Kuller LH, Lasser NL, Oberman A, Miller ST, Morris C, Whelton PK, Hennekens CH, for the Trials of Hypertension Prevention (TOHP) Collaborative Research Group. Design of a multicenter trial to evaluate long-term life-style intervention in adults with high-normal blood pressure levels. Trials of Hypertension Prevention (Phase II).. Ann Epidemiol 1995;5(2):130-139. [MedLine: 95316189].

Hollis JF, Satterfield S, Smith F, Fouad M, Allender PS, Borhani N, Charleston J, Hirlinger M, King N, Schultz R, Sousoulas BG, on behalf of Trials of Hypertension Prevention (TOHP) Collaborative Research Group. Recruitment for phase II of the Trials of Hypertension Prevention. Effective strategies and predictors of randomization.. Ann Epidemiol 1995;5(2):140-148. [MedLine: 95316190].

Hunt SC, Cook NR, Oberman A, Cutler JA, Hennekens $\mathrm{CH}$, Allender PS, Walker WG, Whelton PK, Williams RR. Angiotensinogen genotype, sodium reduction, weight loss, and prevention of hypertension. Trials of Hypertension Prevention, Phase II. Hypertension 1998;32(3):393-401. [MedLine: 98413188].

Lasser VI, Raczynski JM, Stevens VJ, Mattfeldt-Beman M, Kumanyika S, Evans M, Danielson E, Dalcin A, Batey DM, Belden LK, Brewer AA for the Trials Of Hypertension Prevention (TOPH) Collaborative Research Group. Trials of Hypertension Prevention, phase II. Structure and content of the weight loss and dietary sodium reduction interventions. Trials of Hypertension Prevention (TOHP) Collaborative Research Group. Ann Epidemiol 1995;5(2): 156-164. [MedLine: 95316192].

* The Trials of Hypertension Prevention Collaborative Research Group. Effects of weight loss and sodium reduction intervention on blood pressure and hypertension incidence in overweight people with high-normal blood pressure. The Trials of Hypertension Prevention, phase II. Arch Intern Med 1997;157(6):657-667. [MedLine: 97236001].

\section{TONE \{published data only\}}

Appel LJ, Espeland M, Whelton PK, Dolecek T, Kumanyika S, Applegate WB, Ettinger WH Jr, Kostis JB, Wilson AC, Lacy C, Miller ST. Trial of Nonpharmacologic Intervention in the Elderly (TONE). Design and rationale of a blood pressure control trial. Ann Epidemiol 1995;5(2):119-129. [MedLine: 95316188].

Appel LJ, Espeland MA, Easter L, Wilson AC, Folmar S, Lacy CR. Effects of redcued sodium intake on hypertension control in older individuals. Results from the Trial of Nonpharmacological Interventions in the Elderly (TONE). Arch Intern Med 2001;161(5):685-693. [MedLine: 21152543].

Bahnson JL, Whelton PK, Appel LJ, Espeland MA, Wofford JL, Rosen R, Wilson AC, Lacey CR, Rutan G, Hogan P, Tayback M, Dolecek TA, Shindler D. Baseline characteristics of randomized participants in the trial of nonpharmacologic intervention in the elderly (TONE). Disease Management and Clinical Outcomes 1997;1(2): 61-68.

Espeland MA, Whelton PK, Kostis JB, Bahnson JL, Ettinger WH, Cutler JA, Appel LJ, Kumanyika S, Farmer D, Elam J, Wilson AC, Applegate WB. Predictors and mediators of successful long-term withdrawal from antihypertensive medications. Arch Fam Med 1999;8(3):228-236. [MedLine: 99266360].

Kostis JB, Espeland MA, Appel LJ, Johnson KC, Pierce J, James L. Does withdrawal of antihypertensive medication increase the risk of cardiovascular events?. Am J Cardiol 1998;82(12):1501-1508. [MedLine: 99089451].

* Whelton PK, Appel LJ, Espeland MA, Applegate WB, Ettinger WH Jr, Kostis JB, Kumanyika S, Lacy CR, Johnson KC, Folmar S, Cutler JA for the TONE Collaborative Research Group. Sodium reduction and weight loss in the treatment of hypertension in older persons: a randomized controlled trial of nonpharmacologic interventions in the elderly (TONE). JAMA 1998;279(11):839-846. [MedLine: 98175759].

Whelton PK, Bahnson J, Appel LJ, Charleston J, Cosgrove N, Espeland MA, Folmar S, Hoagland D, Krieger S, Lacy C, Lichtermann L, Oates WF, Tayback M, Wilson AC. Recruitment in the Trial of Nonpharmacologic Intervention in the Elderly (TONE). J Am Geriatr Soc 1997;45(2): 185-193. [MedLine: 97185836].

\section{References to studies excluded from this review}

\section{Aberg 1989}

* Aberg H, Tibblin G. Addition of non-pharmacological methods of treatment in patients on antihypertensive drugs: results of previous medication, laboratory tests and life quality. Journal of Internal Medicine 1989;226(1):39-46. [MedLine: 89328303]. 
Ambard 1904

Ambard L. Causes de l'hypertension arterielle. Archives of General Medicine 1904;1:520-533.

\section{Ambrosioni 1982}

Ambrosioni E, Costa F, Borghi C, montebugnoli M, Giordani M, Vasconi L. Effects of moderate salt restriction and high potassium intake on intralymphocytic sodium content and pressor response to stress in borderline hypertension. Clinical Science 1982;63:231S-234S.

\section{Anderson 1990}

* Anderson A, Morgan T. Interaction of enalapril with sodium restriction, diuretics, and slow-channel calcium-blocking drugs. Nephron 1990;55(Suppl 1):70-72. [MedLine: 90265449].

\section{Berglund 1989}

Berglund A, Andersson OK, Berglund G, Fagerberg B. Antihypertensive effect of diet compared with drug treatment in obese men with mild hypertension. BMJ 1989; 299(6697):480-485. [MedLine: 90001793].

Bompiani 1988

Bompiani GD, Cerasola G, Morici M, Condorelli M, Trimarco B, de Luca N, Leonetti G, Sampieri L, Cuspidi C, Cottone S, D'Ignoto G. Effects of moderate low sodium / high potassium diet on essential hypertension: results of a comparative study. Int Journal of Clinical Phrmacology, Therapy and Toxicology 1988;26(3):129-132. [MedLine: 88314399].

\section{Cappuccio 1997}

* Cappuccio FP, Markandu ND, Carney C, Sagnella GA, MacGregor GA. Double-blind randomised trial of modest salt restriction in older people [see comments]. Lancet 1997; 350(9081):850-854. [MedLine: 97456646].

\section{Carney 1975}

Carney S, Morgan T, Wilson M, Matthews G, Roberts R. Sodium restriction and thiazide diuretics in the treatment of hypertension. Medical Journal of Australia 1975;1(26): 803-807. [MedLine: 75215971].

\section{Corcoran 1951}

* Corcoran AC, Taylor RD, Page IH. Controlled observations on the effect of low sodium dietotherapy in essential hypertension. Circulation 1951;III:1-16.

\section{Dahl 1958}

Dahl L, Silver L, Christie R. The role of salt in teh fall of blood pressure accompanying reduction in obesity. New England Journal of Medicine 1958;258:1186-1192. [MedLine: 58095969].

\section{DASH}

Appel LJ, Moore TJ, Obarzanek E, Vollmer WM, Svetkey LP, Sacks FM, Bray GA, Vogt TM, Cutler JA, Windhauser MM, Lin PH, Karanja N. A clinical trial of the effects of dietary patterns on blood pressure. DASH Collaborative Research Group. N Engl J Med 1997;336(16):1117-1124. [MedLine: 97238752]. Sacks FM, Appel LJ, Moore TJ, Obarzanek E, Vollmer WM, Svetkey LP, Bray GA, Vogt TM, Cutler JA, Windhauser MM, Lin PH, Karanja N. A dietary approach to prevent hypertension: a review of the dietary approaches to stop hypertension (DASH) study. Clinical Cardiology 1999;22(7 Supplement):III 6-10. [MedLine: 99338488]. Sacks FM, Svetkey LP, Vollmer WM, Appel LJ, Bray GA, Harsha D, Obarzanek E, Conlin PR, Miller ERI, Simons-Morton DG, Karanja N, Lin P-H, Aickin M, Most-Windhauser MM, Moore TJ, Proschan MA, Cutler JA. Effects on blood pressure of reduced dietary sodium and the Dietary Approaches to Stop Hypertension (DASH) diet. New England Journal of Medicine 2001;344(1):3-10. [MedLine: 21012263].

Svetkey LP, Simons-Morton DG, Vollmer WM, Appel LJ, Conlin PR, Ryan DH, Ard J, Kennedy BM. Effects of dietary patterns on blood pressure: subgroup analysis of the dietary approaches to stop hypertension (DASH) randomized clinical trial. Archives of Internal Medicine 1999;159(3):285-293. [MedLine: 99142647].

\section{DISH}

* Blaufox MD, Langford HG, Oberman A, Hawkins CM, Wassertheil SS, Cutter GR. Effect of dietary change on the return of hypertension after withdrawal of prolonged antihypertensive therapy (DISH). Dietary Intervention Study of Hypertension. J Hypertens Suppl 1984;2(3): S179-S181. [MedLine: 86199066].

Langford HG, Blaufox MD, Oberman A, Hawkins CM, Curb JD, Cutter GR, Wassertheil SS, Pressel S, Babcock C, Abernethy JD, et a. Dietary therapy slows the return of hypertension after stopping prolonged medication. JAMA 1985;253(5):657-664. [MedLine: 85108285].

Wassertheil SS, Blaufox MD, Langford HG, Oberman A, Cutter G, Pressel S. Prediction of response to sodium intervention for blood pressure control. J Hypertens Suppl 1986;4(5):S343-S346. [MedLine: 87197751]. Wassertheil SS, Langford HG, Blaufox MD, Oberman A, Hawkins M, Levine B, Cameron M, Babcock C, Pressel $\mathrm{S}$, Caggiula A, et a. Effective dietary intervention in hypertensives: sodium restriction and weight reduction. $J$ Am Diet Assoc 1985;85(4):423-430. [MedLine: 85158652].

Dole 1951

Dole V, Dahl L, Cotzias G, Dziewiatkowski D, Harris C. Dietary treatment of hypertension. II Sodium depletion as related to the therapeutic effect. Journal of Clinical Investigation 1951;30:584-595.

\section{Dubbert 1995}

Dubbert PM, Cushman WC, Meydrech EF, Rowland AK, Maury P. Effects of dietary instruction and sodium excretion feedback in hypertension clinic patients. Behavior Therapy 1995;26(4):721-732. [MedLine: 1995342245].

Erwteman 1984

* Erwteman TM, Nagelkerke N, Lubsen J, Koster M, Dunning AJ. Beta blockade, diuretics, and salt restriction for the management of mild hypertension: a randomised double blind trial. Br Med J Clin Res Ed 1984;289(6442): 406-409. [MedLine: 84281599].

\section{Evers 1987}

Evers SE, Bass M, Donner A, McWhinney IR. Lack of impact of salt restriction advice on hypertensive patients. 
Preventive Medicine 1987;16(2):213-220. [MedLine: 87231784].

\section{Fagerberg 1984}

* Fagerberg B, Andersson OK, Isaksson B, Bjorntorp P. Blood pressure control during weight reduction in obese hypertensive men: separate effects of sodium and energy restriction. Br Med J Clin Res Ed 1984;288(6410):11-14. [MedLine: 84081362].

\section{Geleijnse 1995}

* Geleijnse JM, Witteman JC, Bak AA, den BJ, Grobbee DE. Long-term moderate sodium restriction does not adversely affect the serum HDL/total cholesterol ratio. J Hum Hypertens 1995;9(12):975-979. [MedLine: 96362947].

\section{Gillum 1983}

* Gillum RF, Prineas RJ, Jeffery RW, Jacobs DR, Elmer PJ, Gomez O, Blackburn H. Nonpharmacologic therapy of hypertension: the independent effects of weight reduction and sodium restriction in overweight borderline hypertensive patients. Am Heart J 1983;105(1):128-133. [MedLine: 83097284].

\section{Grimm 1990}

* Grimm RH Jr, Neaton JD, Elmer PJ, Svendsen KH, Levin J, Segal M, Holland L, Witte LJ, Clearman DR, Kofron P, La Bounty RK, Crow R, Prineas RJ. The influence of oral potassium chloride on blood pressure in hypertensive men on a low-sodium diet. N Engl J Med 1990;322(9):569-574. [MedLine: 90158725].

HCP

Stamler R, Grimm RH Jr, Dyer AR, Talano JV, Prineas R, Crow R, Berman R, Gosch FC, Elmer P, Stamler J. Cardiac status after four years in a trial on nutritional therapy for high blood pressure. Arch Intern Med 1989;149(3): 661-665. [MedLine: 89149275].

Stamler R, Stamler J, Grimm R, Dyer A, Gosch FC, Berman R, Elmer P, Fishman J, Van Heel N, Civinelli J, Hoeksema R. Nonpharmacological control of hypertension. Prev Med 1985;14(3):336-345. [MedLine: 86042572].

Stamler R, Stamler J, Grimm R, Gosch F, Dyer A, Berman R, Civinelli J, Elmer P, Fishman J, Van Heel N, McDonald A, McKeever P. Trial on control of hypertension by nutritional means: three-year results. J Hypertens Suppl 1984;2(3):S167-S170. [MedLine: 87141518].

Stamler R, Stamler J, Grimm R, Gosch FC, Elmer P, Dyer A, Berman R, Fishman J, Van Heel N, Civinelli J, McDonald A. Nutritional therapy for high blood pressure. Final report of a four-year randomized controlled trial-the Hypertension Control Program. JAMA 1987;257(11): 1484-1491. [MedLine: 87141518].

Stamler R, Stamler J, Grimm R, Gosch FC, Elmer P, Dyer A, Berman R, Fishman J, Van Heel N, Civinelli J, McDonald A. Nutritional therapy for high blood pressure. Final report of a four-year randomized controlled trial-the Hypertension Control Program. JAMA 1987;257(11): 1484-1491. [MedLine: 86199063].

\section{Henningsen 1980}

* Henningsen NC. Salt and essential hypertension.

[Swedish]. Var Foda 1980;32(6/7):345-354.

Holly 1981

* Holly JM, Goodwin FJ, Evans SJ, Vandenburg MJ,

Ledingham JM. Re-analysis of data in two Lancet papers on the effect of dietary sodium and potassium on blood pressure. Lancet 1981;2(8260-61):1384-1387. [MedLine: 82079762].

\section{Iwaoka 1994}

* Iwaoka T, Umeda T, Inoue J, Naomi S, Sasaki M, Fujimoto Y, Gui C, Ideguchi Y, Sato T. Dietary $\mathrm{NaCl}$ restriction deteriorates oral glucose tolerance in hypertensive patients with impairment of glucose tolerance. $A m J$ Hypertens 1994;7(5):460-463. [MedLine: 94338640].

\section{Jula 1990}

* Jula A, Ronnemaa T, Rastas M, Karvetti RL, Maki J. Long-term nopharmacological treatment for mild to moderate hypertension. J Intern Med 1990;227(6): 413-421. [MedLine: 90278339].

\section{Jula 1992a}

* Jula A, Ronnemaa T, Tikkanen I, Karanko H. Responses of atrial natriuretic factor to long-term sodium restriction in mild to moderate hypertension. J Intern Med 1992;231(5): 521-529. [MedLine: 92291706].

\section{Jula 1992b}

* Jula AM, Ronnemaa TE, Piha SJ, Maki JP. Response of diastolic blood pressure to long-term sodium restriction is posture related. Scandinavian Journal of Clinical and Laboratory Investigation 1992;52(3):159-167. [MedLine: 9303401].

\section{Jula 1994}

* Jula AM, Karanko HM. Effects on left ventricular hypertrophy of long-term nonpharmacological treatment with sodium restriction in mild-to-moderate essential hypertension. Circulation 1994;89(3):1023-1031. [MedLine: 94170458].

\section{Koopman 1990}

* Koopman H, Spreeuwenberg C, Westerman RF, Donker AJ. Dietary treatment of patients with mild to moderate hypertension in a general practice: a pilot intervention study (2). Beyond three months. J Hum Hypertens 1990;4 (4):372-374. [MedLine: 91080076].

Koopman H, Spreeuwenberg C, Westerman RF, Donker AJM. Dietary treatment of patients with mild to moderate hypertension in a general practice: a pilot intervention study. (2) Beyond 3 months. Journal of Human Hypertension 1990;4(4):372-374. [MedLine: 91080076].

\section{Korhonen 1999}

Korhonen MH, Litmanen H, Rauramaa R, Vaisanen SB, Niskanen L, Uusitupa J. Adherence to the salt restriction diet among people with mildly elevated blood pressure. European Jouranl of Clinical Nutrition 1999;53(11): 880-885. [MedLine: 20025972]. 
Logan 1986

Logan AG. Sodium manipulation in the management of hypertension. The view against its general use. Canadian Journal of Physiology and Pharmacology 1986;64(6):793-802. [MedLine: 87001697].

* Logan AG, Flanagan PT, Haynes RB. Effect of dietary sodium restriction alone in the treatment of mild hypertension. unpublished.

\section{MacGregor 1982a}

MacGregor GA, Markandu ND, Sagnella GA. Dietary sodium restriction in normotensive subjects and patients with essential hypertension. Clin Sci 1982;63:399S-402S.

\section{MacGregor 1982b}

MacGregor GA, Markandu ND, Best FE, Elder DM, Cam JM, Sagnella GA, Squires M. Double-blind randomised crossover trial of moderate sodium restriction in essential hypertension. Lancet 1982;1(8268):351-355. [MedLine: 82123995].

\section{MacGregor 1989}

* MacGregor GA, Markandu ND, Sagnella GA, Singer DR, Cappuccio FP. Double-blind study of three sodium intakes and long-term effects of sodium restriction in essential hypertension. Lancet 1989;2(8674):1244-1247. [MedLine: 90065792].

\section{Magnani 1976}

Magnani B, Ambrosioni E, Agosta R, Racco F. Comparison of the effects of pharmacological therapy anda low-sodium diet on mild hypertension. Clin Sci Mol Med Suppl 1976;3: 625S-626S. [MedLine: 77161090].

\section{McDonald 1988}

* McDonald AM, Dyer AR, Liu K, Stamler R, Gosch FC, Grimm R, Berman R, Stamler J. Sodium, lithium-countertransport and blood pressure control by nutritional intervention in 'mild' hypertension. J Hypertens 1988;6(4):283-291. [MedLine: 88244364].

\section{Morgan 1988}

Morgan T, Anderson A. Interaction in hypertensive men between sodium intake, converting enzyme inhibitor (enalapril), plasma renin and blood pressure control. Journal of Human Hypertension 1988;1(4):311-315. [MedLine: 89125550].

Muhlhauser 1993

* Muhlhauser I, Sawicki PT, Didjurgeit U, Jorgens V, Trampisch HJ, Berger M. Evaluation of a structured treatment and teaching programme on hypertension in general practice. Clin Exp Hypertens 1993;15(1):125-142. [MedLine: 93222829].

\section{Myers 1989}

Myers JB. Reduced sodium chloride intake normalises blood pressure distribution. Journal of Human Hypertension 1989;3(2):97-104. [MedLine: 89342389].

\section{Nestel 1993}

* Nestel PJ, Clifton PM, Noakes M, McArthur R, Howe PR. Enhanced blood pressure response to dietary salt in elderly women, especially those with small waist:hip ratio.
Journal of Hypertension 1993;11(12):1387-1394. [MedLine: 94179778].

\section{Neyses 1985}

* Neyses L, Dorst K, Michaelis J, Berres M, Philipp T, Distler A, Losse H, Vetter H, Epstein FH, Vetter W. Compliance with salt restriction as a limiting factor in the primary prevention of hypertension. J Hypertens Suppl 1985;3(1):S87-S90. [MedLine: 87253502].

\section{Nicholson 1986}

* Nicholson JP, Resnick LM, Laragh JA. The impact of dietary sodium intake on the hypotensive response of verapamil in essential hypertension. J Clin Hypertens 1986; 2(3 Suppl):143S-147S. [MedLine: 87085718].

\section{Nicholson 1987}

* Nicholson JP, Resnick LM, Laragh JH. The antihypertensive effect of verapamil at extremes of dietary sodium intake. Ann Intern Med 1987;107(3):329-334. [MedLine: 87297036].

\section{Nowson 1988}

* Nowson CA, Morgan TO. Change in blood pressure in relation to change in nutrients effected by manipulation of dietary sodium and potassium. Clinical and Experimental Pharmacology and Physiology 1988;15(3):225-242. [MedLine: 90150703].

\section{Nugent 1984}

Nugent CA, Carnahan JE, Sheehan ET, Myers C. Salt restriction in hypertensive patients. Comparison of advice, education and group management. Archives of Internal Medicine 1984;144(7):1415-1417. [MedLine: 84230406].

\section{ODES}

Anderssen S, Holme I, Urdal P, Hjermann I. Diet and exercise intervention have favourable effects on blood pressure in mild hypertensives: the Oslo Diet and Exercise Study. (ODES). Blood Pressure 1995;4(6):343-349. [MedLine: 96356286].

\section{Omvik 1986}

* Omvik P, Lund-Johansen P. Is sodium restriction effective treatment of borderline and mild essential hypertension? A long-term haemodynamic study at rest and during exercise. Journal of Hypertension 1986;4(5):535-541. [MedLine: 87084739].

\section{Omvik 1995}

* Omvik P, Myking OL. Unchanged central hemodynamics after six months of moderate sodium restriction with or without potassium supplement in essential hypertension. Blood Press 1995;4(1):32-41. [MedLine: 95253445].

\section{Parijs 1973}

* Parijs J, Joossens JV, Van der Linden L, Verstreken G, Amery AK. Moderate sodium restriction and diuretics in the treatment of hypertension. American Heart Journal 1973;85(1):22-34. [MedLine: 73052205].

\section{Perera 1947}

Perera G, Blood D. The relationship of sodium choride to hypertension. Journal of Clinical Investigation 1947;26: 1109-1117. 
Priddle 1962

Priddle W. Hypertension-sodium and potassium studies.

Journal of the Canadian Medical Association 1962;86(1):1-9.

Rissanen 1985

* Rissanen A, Pietinen P, Siljamaki OU, Piirainen H, Reissel P. Treatment of hypertension in obese patients: efficacy and feasibility of weight and salt reduction programs. Acta Med Scand 1985;218(2):149-156. [MedLine: 86047190].

Roca-Cusachs 1991

* Roca-Cusachs A, Sort D, Altimira J, Bonet R, Guilera E, Monmany J, Nolla J. The impact of a patient education programme in the control of hypertension. J Hum Hypertens 1991;5(5):437-441. [MedLine: 92122169].

\section{Sagnella 1987}

* Sagnella GA, Markandu ND, Buckley MG, Singer DR, Sugden AL, Shore AC, MacGregor GA. Plasma atrial natriuretic peptide in essential hypertension: effects of changes in dietary sodium. Br Med J Clin Res Ed 1987;295 (6595):417-418. [MedLine: 88001459].

\section{Shibata 1979}

Shibata H, Hatano S. Mild hypertension: natural history and management. Bath: Pitman Medical, 1979.

\section{Singer 1984}

Singer DR, Markandu ND, Cappuccio FP, Miller MA, Sagnella GA, Skrabal F, Gasser RW, Finkenstedt G, Rhomberg HP, Lochs A. Low-sodium diet versus low-sodium/high-potassium diet for treatment of hypertension. Klinische. Wochenschrift 1984;62(3):124-128. [MedLine: 84165933].

\section{Singer 1995}

Singer DR, Markandu ND, Cappuccio FP, Miller MA, Sagnella GA, MacGregor GA. Reduction of salt intake during converting enzyme inhibitor treatment compared with addition of a thiazide. Hypertension 1995;25(5): 1042-1044. [MedLine: 95255896].

\section{Stamler 1989}

Stamler R, Stamler J, Gosch FC, Civinelli J, Fishman J, McKeever P, McDonald A, Dyer AR. Primary prevention of hypertension by nutritional-hygienic means. Final report of a randomized, controlled trial [published erratum appears in JAMA 1989 Dec 8;262(22):3132]. JAMA 1989;262 (13):1801-1807. [MedLine: 89382841]. Stamler R, Stamler J, Gosch FC, McDonald AM. Primary prevention of hypertension-a randomized controlled trial. Ann Clin Res 1984;16(Supplement 43):136-142. [MedLine: 85223780].

\section{TAIM}

Blaufox MD, Lee HB, Davis B, Oberman A, WassertheilSmoller S, Langford H. Renin predicts diastolic blood pressure response to nonpharmacologic and pharmacologic therapy. JAMA 1992;267(9):1221-1225. [MedLine: 92167529].

Davis BR, Blaufox MD, Oberman A, Wassertheil-Smoller S, Zimbaldi N, Cutler JA, Kirchner K, Langford HG. Reduction in long-term antihypertensive medication requirements. Effects of weight reduction by dietary intervention in overweight persons with mild hypertension. Arch Intern Med 1993;153(15):1773-1782. [MedLine: 93326077].

Davis BR, Oberman A, Blaufox MD, Wassertheil-Smoller S, Hawkins CM, Cutler JA, Zimbaldi N, Langford HG. Effect of antihypertensive therapy on weight loss. The Trial of Antihypertensive Interventions and Management Research Group. Hypertension 1992;19(4):393-399. [MedLine: 92210170].

Davis BR, Oberman A, Blaufox MD, Wassertheil-Smoller S, Zimbaldi N, Kirchner K, Wylie-Rosett J, Langford HG. Lack of effectiveness of a low-sodium/high-potassium diet in reducing antihypertensive medication requirements in overweight persons with mild hypertension. TAIM Research Group. Trial of Antihypertensive Interventions and Management. Am J Hypertens 1994;7(10 Pt 1): 926-932. [MedLine: 95127141].

Langford HG, Davis BR, Blaufox D, Oberman A, Wassertheil-SmollerS, Hawkins M, Zimbaldi N. Effect of drug and diet treatment of mild hypertension on diastolic blood pressure. The TAIM Research Group. Hypertension 1991;17(2):210-217. [MedLine: 91122830].

Oberman A, Wassertheil-Smoller S, Langford HG, Blaufox MD, Davis BR, Blaszkowski T, Zimbaldi N, Hawkins CM. Pharmacologic and nutritional treatment of mild hypertension: changes in cardiovascular risk status [see comments]. Ann Intern Med 1990;112(2):89-95. [MedLine: 90103317].

Wassertheil-Smoller S, Davis BR, Breuer B, Chee JC, Oberman A, Blaufox MD. Differences in precision of dietary estimates among different population subgroups. Ann Epidemiol 1993;3(6):619-628. [MedLine: 95005518]. Wassertheil-Smoller S, Oberman A, Blaufox MD, Davis B, Langford $\mathrm{H}$. The Trial of Antihypertensive Interventions and Management (TAIM) Study. Final results with regard to blood pressure, cardiovascular risk, and quality of life [see comments]. Am J Hypertens 1992;5(1):37-44. [MedLine: 92144045].

Wylie-Rosett J, Wassertheil-Smoller S, Blaufox MD, Davis BR, Langford HG, Oberman A, Jennings S, Hataway H, Stern J, Zimbaldi N. Trial of antihypertensive intervention and management: greater efficacy with weight reduction than with a sodium-potassium intervention. J Am Diet Assoc 1993;93(4):408-415. [MedLine: 93203528].

\section{TOMHS}

* Elmer PJ, Grimm R Jr, Laing B, Grandits G, Svendsen K, Van Heel N, Betz E, Raines J, Link M, Stamler J, Neaton J for the TOMHS Research Group. Lifestyle intervention: results of the Treatment of Mild Hypertension Study (TOMHS). Prev Med 1995;24(4):378-388. [MedLine: 96076094].

Neaton JD, Grimm RH Jr, Prineas RJ, et al. Treatment of mild hypertension study: final results. Journal of the American Medical Association 1993;270(6):713-724. [MedLine: 93329754].

Stamler J, Prineas RJ, Neaton JD, et al. Background and design of the new U.S. trial on diet and drug treatment 
of "mild" hypertension (TOMHS). American Journal of Cardiology 1987;59(14):51G-60G. [MedLine: 87238420]. Treatment of Mild Hypertension Research Group. The treatment of mild hypertension study. A randomized, placebo-controlled trial of a nutritional-hygienic regimen along with various drug monotherapies. Archives of Internal Medicine 1991;151(7):1413-1423. [MedLine: 91290967].

\section{Velloso 1991}

* Velloso LG, Alonso RR, Ciscato CM, Barretto AC, Bellotti G, Pileggi F. [Diet with usual quantity of salt in hospital treatment of congestive heart insufficiency]. Arq Bras Cardiol 1991;57(6):465-468. [MedLine: 92398510].

\section{Watt 1983}

Watt GC, Edwards C, Hart JT, Hart M, Walton P, Foy CJ. Dietary sodium restriction for mild hypertension in general practice. British Medical Journal Clinical Research.Ed 1983; 286(6363):432-436. [MedLine: 83102255].

\section{Watt 1986}

* Watt GC, Foy CJ, Hart JT. Dietary sodium and blood pressure in young people with and without familial predisposition to high blood pressure. J Clin Hypertens 1986;2(2):141-147. [MedLine: 87010734].

\section{Weinberger 1988}

* Weinberger MH, Cohen SJ, Miller JZ, Luft FC, Grim CE, Fineberg NS. Dietary sodium restriction as adjunctive treatment of hypertension. JAMA 1988;259 (17):2561-2565. [MedLine: 88188298].

\section{Wing 1984}

Wing RR, Caggiula AW, Nowalk MP, Koeske R, Lee $S$, Langford $H$. Dietary approaches to the reduction of blood pressure: the independence of weight and sodium/ potassium interventions. Preventive Medicine 1984;13(3): 233-244. [MedLine: 85038455].

\section{Zoccali 1993}

* Zoccali C, Mallamaci F, Leonardis D, Romeo M. Randomly allocated crossover study of various levels of sodium intake in patients with mild hypertension. $J$ Hypertens Suppl 1993;11(Suppl 5):S326-S327. [MedLine: 94210208].

\section{Additional references}

\section{Alam 1999}

Alam S, Johnson AG. A meta-analysis of randomised controlled trials (RCT) among healthy normotensive and essential hypertensive elderly patients to determine the effect of high salt $(\mathrm{NaCl})$ diet of blood pressure. J Hum Hypertens 1999;13(6):367-374. [MedLine: 99335071].

\section{Alderman 1995}

Alderman MH, Madhavan S, Cohen H, Sealey JE, Laragh $\mathrm{JH}$. Low urinary sodium is associated with greater risk of myocardial infarction among treated hypertensive men. Hypertension 1995;25(6):1144-1152. [MedLine: 95286216].

\section{Alderman 1997}

Alderman MH, Ooi WL, Cohen H, Madhavan S, Sealey JE, Laragh JH. Plasma renin activity: a risk factor for myocardial infarction in hypertensive patients. American Journal of Hypertension 1997;10(1):1-8. [MedLine: 97160946].

\section{Alderman 1998}

Alderman MH, Cohen H, Madhavan S. Dietary sodium intake and mortality: the National Health and Nutrition Examination Survey (NHANES I). Lancet 1998;351(9105): 781-785. [MedLine: 98178771].

\section{Allender 1996}

Allender PS, Cutler JA, Follmann D, Cappuccio FP, Pryer J, Elliott P. Dietary calcium and blood pressure: a meta-analysis of randomized clinical trials. Annals of Internal Medicine 1996;124(9):825-831. [MedLine: 96188897].

Anonymous 2000 Anonymous. In: Clarke M, Oxman AD, editor(s). Cochrane Reviewer's Handbook 4.1 [updated June 2000]. Oxford: Update Software, 2000. Oxford: Update Software, 2000.

\section{Barker 1998}

Barker DJP. Mothers, babies and health in later life. Second Edition. Edinburgh: Churchill Livingstone, 1998.

\section{Berkley 1995}

Berkey CS, Hoaglin DC, Mosteller F, Colditz GA. A random-effects regression model for meta-analysis. Statistics in Medicine 1995;14(4):395-411. [MedLine: 95265785].

\section{Brand 1999}

Brand MB, Mulrow CD, Chiquette E, Angel L, Cornell J, Summerbell CD, Anagnostelis B, Grimm RJ. Weight reduction through dieting for control of hypertension in adults. In: Cochrane Library, 1, 1999. Oxford: Update Software.

\section{Cappuccio 1991}

Cappuccio FP, MacGregor GA. Does potassium supplementation lower blood pressure? A meta-analysis of published trials. Journal of Hypertension 1991;9(5):465-473. [MedLine: 91311080].

\section{Cutler 1997}

Cutler JA, Follmann D, Allender PS. Randomized trials of sodium reduction: an overview. American Journal of Clinical Nutrition 1997;65(2 Suppl):643S-651S. [MedLine: 97174900].

\section{DoH 2001}

Department of Health. The Annual Report of the Chief Medical Officer of the Department on Health 2001. Department of Health 2001.

\section{Donner 1982}

Donner A. An empirical study of cluster randomization. International Journal of Epidemiology 1982;11(3):283-286. [MedLine: 83029945].

\section{Ebrahim 1996}

Ebrahim S, Davey Smith G. Health promotion in older people for the prevention of coronary heart disease and stroke. London: Health Education Authority, 1996.

\section{Ebrahim 1998}

Ebrahim S, Davey Smith G. Lowering blood pressure: a systematic review of sustained effects of non-pharmacological 
interventions. Journal of Public Health Medicine 1998;20 (4):441-448. [MedLine: 99120827].

\section{Elliott 1996}

Elliott P, Stamler J, Nichols R, Dyer AR, Stamler R, Kesteloot H, Marmot M. Intersalt revisited: further analyses of 24 hour sodium excretion and blood pressure within and across populations. Intersalt Cooperative Research Group. [erratum appears in BMJ 1997 Aug 23;315(7106): 458.]. BMJ 1996;312(7041):1249-1253. [MedLine: 96225304].

\section{Follman 1992}

Follman D, Elliott P, Suh I, Cutler J. Variance imputation for overviews of clinical trails with continuous response. J Clin Epidemiol 1992;45(7):769-773. [MedLine: 92317975].

\section{Graudal 1998}

Graudal NA, Galloe AM, Garred P. Effects of sodium restriction on blood pressure, renin, aldosterone, catecholamines, cholesterols and triglyceride: a meta-analysis. JAMA 1998;279(17):1383-1391. [MedLine: 98241203].

\section{Griffith 1999}

Griffith LE, Guyatt GH, Cook RJ, Bucher HC, Cook DJ. The influence of dietary and non-dietary calcium supplementation on blood pressure. An updated metaanalysis of randomized controlled trials. American Journal of Hypertension 1999;12(1 Pt 1):84-92. [MedLine: 99173714].

\section{Hauck 1991}

Hauck WW, Gilliss CL, Donner A, Gortner S. Randomization by cluster. Nursing Research 1991;40(6): 356-358. [MedLine: 92066521].

\section{He 1999}

He J, Ogden LG, Vupputuri S, Bazzano LA, Loria C, Whelton PK. Dietary sodium intake and subsequent risk of cardiovascular disease in overweight adults. JAMA 1999; 282(21):2027-2034. [MedLine: 20057342].

He 2001

He FJ, MacGregor GA. Neonatal salt intake and blood pressure. Lancet 2001;357(9271):1880. [MedLine: 21307932].

\section{Hofman 1983}

Hofman A, Hazebroek A, Valkenburg HA. A randomized trial of sodium intake and blood pressure in newborn infants. JAMA 1983;250(3):370-373. [MedLine: 83216582].

\section{Hooper 2000}

Hooper L, Summerbell CD, Higgins JPT, Thompson RL, Clements G, Capps N, Davey Smith G, Riemersma RA, Ebrahim S. Reduced or modified dietary fat for prevention of cardiovascular disease. In: Cochrane Library, 3, 2000.Oxford: Update Software.10.1002/ 14651858.CD002137

\section{Jurgens 2003}

Jurgens G, Graudal NA. Effects of low sodium diet versus high sodium diet on blood pressure, renin, aldosterone, catecholamines, cholesterols, and triglyceride. [same]. In: Cochrane Library, 2, 2003.Oxford, UK: Update Software.10.1002/14651858.CD004022

\section{Law 1991}

Law MR, Frost CD, Wald NJ. By how much does dietary salt reduction lower blood pressure? III-Analysis of data from trials of salt reduction. [erratum appears in BMJ 1991 Apr 20;302(6782):939.]. BMJ 1991;302(6780):819-824. [MedLine: 91223292].

Lucas 1988

Lucas A, Morley R, Husdon GJ, Bamford MF, Boon A, Crowle P, Dossetor JF, Pearse R. Early sodium intake and later blood pressure in preterm infants. Archives of Disease in Childhood 1988;63(6):656-657. [MedLine: 88268226].

MacGregor 1996

MacGregor GA, Sever PS. Salt - overwhelming evidence but still no action: can a consensus be reached with the food industry? CASH (Consensus Action on Salt and Hypertension). BMJ 1996;312(7041):1287-1289. [MedLine: 96225315].

\section{MAFF 1999}

MAFF. National Food Survey, 1998. Annual report of food expenditure, consumption and nutrient intakes. London: HMSO, 1999.

Midgley 1996 Midgley JP, Matthew AG, Greenwood CM, Logan AG. Effect of reduced dietary sodium on blood pressure: a meta-analysis of randomized controlled trials. JAMA 1996; 275(20):1590-1597. [MedLine: 96213904].

\section{Navar 1997}

Navar LG. The kidney in blood pressure regulation and development of hypertension. Medical Clinics of North America 1997;81(5):1165-1198. [MedLine: 97453984].

\section{Ramsay 1999}

Ramsay LE, Williams B, Johnston GD, MacGregor GA, Poston L, Potter JF, Poulter NR, Russell G. British Hypertension Society guidelines for hypertension management 1999: summary. BMJ 1999;319(7210): 630-635. [MedLine: 99402837].

\section{Ramsay 1999a}

Ramsay L, Williams B, Johnston G, MacGregor G, Poston L, Potter J, Poulter N, Russell G. Guidelines for management of hypertension: report of the third working party of the British Hypertension Society. Journal of Human Hypertension 1999;13(9):569-592. [MedLine: 99414258].

\section{Sacks 2001}

Sacks FM, Svetkey LP, Vollmer WM, Appel LJ, Bray GA, Harsha D, Obarzanek E, Conlin PR, Miller ERI, Simons-Morton DG, Karanja N, Lin P-H, Aickin M, Most-Windhauser MM, Moore TJ, Proschan MA, Cutler JA. Effects on blood pressure of reduced dietary sodium and the Dietary Approaches to Stop Hypertension (DASH) diet. DASH-Sodium Collaborative Research Group. New England Journal of Medicine 2001;344(1):3-10. [MedLine: 21012263]. 


\section{Selmer 2000}

Selmer RM, Kristiansen IS, Haglerod A, Graff-Iverson S, Larsen HK, Meyer HE, Bonaa KH, Thelle DS. Cost and health consequences of reducing the population intake of salt. Journal of Epidemiology and Community Health 2000; 54(9):697-702. [MedLine: 20400582].

Sharp 1998

Sharp S. Meta-analysis regression. Stata Technical Bulletin 1998;42:16-22

Singhal 2001

Singhal A, Cole TJ, Lucas A. Early nutrition in preterm infants and later blood pressure: two cohorts after randomised trials. Lancet 2001;357(9254):413-419.

[MedLine: 21119870].

Stamler 1991

Stamler R. Implications of the INTERSALT study. Hypertension 1991;17(1 suppl):I 16-I 20. [MedLine: 91099886]

Taubes 1998

Taubes G. The (political) science of salt. Science 1998;281 (5379):898-907. [MedLine: 98383455].

Tunstall-Pedoe 1997

Tunstall-Pedoe H, Woodward M, Tavendale R, A'Brook $\mathrm{R}$, McCluskey MK. Comparison of the prediction by 27 different factors of coronary heart disease and death in men and women of the Scottish heart health study: cohort study. [erratum appears in BMJ 1998 Jun 20;316(7148):1881.]. BMJ 1997;315(7110):722-729. [MedLine: 97460376].

Tuomilehto 2001

Tuomilehto J, Jousilahti P, Rastenyte D, Moltchanov V, Tanskanen A, Pietinen P, Nissinen A. Urinary sodium excretion and cardiovascular mortality in Finland: a prospective study. Lancet 2001;357(9259):848-851. [MedLine: 21163719].

Whelton 1997

Whelton PK, He J, Cutler JA, Brancati FL, Appel LJ, Follmann D, Klag MJ. Effects of oral potassium on blood pressure. Meta-analysis of randomized controlled clinical trials. Journal of the American Medical Association 1997;277 (20):1624-1632. [MedLine: 97311576].

\section{References to other published versions of this review}

\author{
Hooper 2002 \\ Hooper L, Bartlett C, Davey Smith G, Ebrahim S. Longer \\ electronic version of this review on BMJ website, http:// \\ bmj.com/ [Systematic review of long term effects of advice \\ to reduce dietary salt in adults]. British Medical Journal \\ 2002;325(7365):628-632. \\ * Indicates the major publication for the study
}

\section{SOURCES OF SUPPORT}

\section{External sources of support}

- North West Research and Development Training Fellowship (LH) UK

\section{Internal sources of support}

- University of Manchester UK

- Central Manchester and Manchester Children's University Hospitals NHS Trust UK 